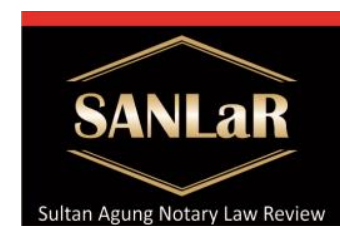

\title{
Problems and Implementation of Government Regulation Number 1 of 2011 Regarding the Transfer of Function of Agricultural Land to Industrial Land
}

\author{
Abdul Kodir ${ }^{*}$, Amin Purnawan ${ }^{* *}$ and Akhmad Khisni ${ }^{* * *}$ \\ *) Student of Master of Notary Law, Faculty of Law, Universitas Islam Sultan Agung \\ (UNISSULA) Semarang \\ E-mail: abdulkodir5577@gmail.com \\ $\left.{ }^{* *}\right)$ Lecturer of Master of Notary Law, Faculty of Law, Universitas Islam Sultan Agung \\ (UNISSULA) Semarang \\ ${ }^{* * *}$ Lecturer of Master of Notary Law, Faculty of Law, Universitas Islam Sultan Agung \\ (UNISSULA) Semarang
}

\begin{abstract}
The threat to disruption of food security due to rampant conversion of agricultural land is very significantagainst land use change according to Government Regulation No. 1 of 2011 concerning the Designation and Transfer of Function of Sustainable Food Agricultural Land in article 35 has regulated limitatively that land that has been designated as Sustainable Food Agricultural Land is protected and prohibited from being converted. The purpose of this study is to determine the implementation of land use change according to Government Regulation No. 1 of 2011 and to find out the legal consequences of the conversion of agricultural land into industrial areas. The method used in this research is sociological juridical method, the specification in this research is descriptive analysis, data used are primary data and secondary data, using data collection by interview and literature study, qualitative data analysis, problems analyzed by theory, legal certainty, and Justice Theory. The results of this study indicate that transfer of function in Government Regulation No. 1 of 2011 concerning the Designation and Transfer of Function of Sustainable Food Agricultural Land in article 35 regulates that land that has been designated as Sustainable Food Agricultural Land is protected and prohibited from being converted. The local government can carry out the conversion of land functions in the context of land acquisition for the public interest or a disaster occurs. Industry is not included in the public interest, which is allowed to use paddy fields for conversion. Regarding law enforcement on the conversion of agricultural land functions, the central and regional governments still consider that development is merely encouraging the improvement of physical infrastructure, which often sacrifices productive agricultural land. The conversion of agricultural land to residential areas, the development of public infrastructure and industrial facilities is quite alarming so that it will have an impact on the national and regional food crisis if not handled seriously. In the midst of the food self-sufficiency target, there needs to be serious steps in law enforcement and maximum protection of productive agricultural land.
\end{abstract}

Keywords: Change of Function of Land; Agricultural Land; Industrial Land. 


\section{Introduction}

Indonesia is a constitutional state as stipulated in Article 1 paragraph (3) of the Constitution of the Republic of Indonesia. In this way, matters relating to the general welfare have been regulated in law in the form of written regulations. As a rule of law, the state guarantees legal certainty, order and protection that has the essence of truth and justice, which means that the state includes every individual, society, government and other state institutions in exercising their rights and obligations that must be based on law.

Land has a very important meaning in human life. The elements contained in the soil are very meaningful in human life. So that land is one of the primary needs for humans. Land is something that is a place for all activities or activities of life and human life. In fact, land plays a major role in efforts to improve community welfare.

Entering the era of globalization, facilities and infrastructure are needed to support the implementation of this development, one of which is land. Land plays an important role as land to realize development, in this case is physical development. As is well known, land cannot be separated from humans because land is an important factor in human life. Land is a place of settlement, a place for human activities, even after death it still requires land. ${ }^{1}$

The Republic of Indonesia, where the structure of the life of the people, including the economy, is mainly still agrarian, so that the earth, water and space as a gift from God Almighty has a very important function to build a just and prosperous society. In Article 33 paragraph (3) of the Basic Law Republic of Indonesia in 1945 states that "The land, water and natural resources contained therein are controlled by the State and used as much as possible for the prosperity of the people". From this article, it can be seen that the State is the largest organization that controls land and has the following authorities:

1. Regulate and administer the designation, use, supply of earth, water and space and determine and regulate legal relationships between people and earth, water and space;

2. Defining and regulating the relationships between people and earth, water and space;

3. Determine and regulate legal relationships between people and legal actions concerning earth, water and space; ${ }^{2}$

Land conversion or conversion of agricultural land is not a new problem. Population growth as well as economic growth demands that infrastructure development in the form of roads, industrial buildings and settlements. This of course must be supported by the availability of land. Conversion of agricultural land is usually carried out directly by the owner of the land or indirectly by other parties which previously preceded by

\footnotetext{
${ }^{1}$ Achmad Chulaemi, Land Acquisition for Certain Purposes in the Context of Development, Semarang: Magazine of Legal Issues Number 1 FH UNDIP, 1992, page 9
} 
buying and selling agricultural land. Many factors influence landowners to convert land or sell their agricultural land, including the price of land, proportion of income, land area, land productivity, land status and government policies. Now farmers or agricultural land owners as well as cultivators of agricultural land are no longer dealing with landlords like in the era of the UUPA of 1960, but are dealing with large capital in industry as well as rich people in cities who buy land in suburban areas and in the countryside. Agricultural land is converted into value into stocks which can be traded at any time through the capital market. So that land transactions means reaching and crossing national territorial boundaries. ${ }^{3}$

The conversion of agricultural land to non-agricultural functions, especially in Cirebon Regency, has increased. Initially, the main objective of changing agricultural land use to non-agriculture is to improve the welfare of the community and the nation's economy. However, its implementation can threaten the certainty of food supply if it is not controlled. Even in the long term, these changes can result in social losses. Agricultural land is land or land designated or suitable for agricultural use to produce agricultural crops or livestock. The agricultural land includes all plantation land, fishponds for fisheries, land for grazing livestock, scrub land used for farming and forest which is the source of livelihood for those who are entitled. ${ }^{4}$

Basically, agricultural land conversion is a natural thing to happen. But in reality, land conversion is a problem because it occurs on agricultural land that is still productive. Various regulations have been issued by the Regional Government to limit the occurrence of this land conversion phenomenon. However, these efforts have not been successful because of the ease of changing the physical condition of the rice fields. Regulations made with the aim of controlling land conversion are generally only an appeal, although some have been written in legislation, but are not equipped with clear sanctions. In addition, conversion is a collective decision so that it is difficult to trace which party is responsible for granting land conversion permits.

However, the practice of changing the function of land to agricultural land is inevitable considering that the District does have an important and strategic role and function to create an industrial structure that has comparative and competitive advantages and increases productivity, is efficient and strengthens national economic stability. The district as one of the bases for highly competitive production and distribution activities needs to be expanded and developed to potential areas. Furthermore, the development and expansion of the District to potential regional areas will support regional economic expansion and decentralizationdevelopment in an effective and efficient manner efforts to strengthen the implementation of regional autonomy. ${ }^{5}$

However Determination of the amount of perennial productive agricultural land (which is maintained) is also needed to maintain the stability and sustainability of food supply

\footnotetext{
${ }^{3}$ Mustofa Suratman, 2013, Use of Land Rights for Industry, Sinar Grafika, Jakarta h. 8

${ }^{4}$ Ali Achmad Chomzah, 2005, Agrarian Law (Indonesian Land), Prestasi Pustaka Publisher, Jakarta, p. 56

${ }^{5}$ Adisasmita, Rahardjo. 2010. "Management of Regional Income and Orchids". Graha Ilmu: Yogjakarta. Pg 137
} 
by considering the population, the area of agricultural land that is currently available, the total area, population growth rate, economic growth targets, plus projected food demand in the future. The flow of permits for land conversion, especially for industrial purposes, has not been centralized or coordinated in just one agency, in this case the BPPT (Integrated Licensing Service Agency) so that the entire application process seems unable to be properly monitored because there can still be found inconsistencies in permit approvals that can be found. harm the applicant for permission or the public interest,in addition to the unpublished detailed mapping of the entire Cirebon Regency area by integrating the initial resource state with the aim of developing the area as a whole, both economic, social, cultural, security, demographic, and others so that areas with unproductive lands can be developed more useful and effective for development such as becoming an economic buffer satellite area in Cirebon Regency. This also aims to optimize the comparative advantage (comparative advantage) between one region and another in Cirebon Regency which synergize with each other and fill the advantages that have been it has.social, cultural, security, demographic, and others so that areas that have unproductive lands can be developed more useful and effective for development, such as becoming an economic buffer satellite area in Cirebon Regency. This also aims to optimize comparative advantage. advantage) between one region and another in Cirebon Regency which synergizes with each other and fills in the advantages it already has.social, cultural, security, demographic, and others so that areas that have unproductive lands can be developed more useful and effective for development, such as becoming an economic buffer satellite area in Cirebon Regency. This also aims to optimize comparative advantage. advantage) between one region and another in Cirebon Regency which synergizes with each other and fills in the advantages it already has.It also aims to optimize the comparative advantage between one region and another in Cirebon Regency which synergizes with each other and fills in the advantages it already has.It also aims to optimize the comparative advantage between one region and another in Cirebon Regency which synergizes with each other and fills in the advantages it already has.

The threat to disruption of food security due to widespread conversion is very significant. Many areas that were previously rice self-sufficient areas have now become areas that import rice from other regions. This threat to food security will not only reduce rice production but will also disrupt economic, social, political stability and general population development. ${ }^{6}$ In the framework of sustainable agricultural development, the protection of agricultural food land is an effort that is inseparable from agrarian reform which includes efforts to organize, control/own in relation to the legal relationship between humans and land. ${ }^{7}$ The provisions on the protection of land for sustainable food agriculture are intended so that certain areas of land may only be used for appropriate food agriculture activities.

\footnotetext{
${ }^{6}$ Nana Apriyana, Agricultural Land Conversion Policy in the Framework of Sustaining Land Resilience, Case Study on Pulau J awa, Ministry of National Development Planning/Bappenas, Jakarta, 2011, pp. 5 ${ }^{7}$ Maria SW Sumarjono, Land in the Perspective of Economic, Social and Cultural Rights, Kompas Gramedia, Jakarta, 2008, p. 95
} 
Strategic efforts in controlling the conversion of agricultural land functions and protecting productive agricultural land need to be supported by a statutory regulation. To protect agricultural food land, the provisions of Act No. 41 of 2009 concerning the Protection of Sustainable Agricultural Land have been established. This provision needs to be further elaborated by the Regional Government as it is determined that the Regency/City Province determines sustainable food agriculture land, one of which is the obligation to determine agricultural areas in the Regional Spatial Planning so that its existence is expected to be sustainable.

In terms of carrying out the land conversion, previously the land owner had to obtain a Land Use Change Permit (IPPT), with the intention of permitting to change land use from agricultural to non-agricultural land. The National Land Agency of the Republic of Indonesia (BPNRI) has the authority to issue technical considerations for land in the context of issuing the IPPT. However, the conditions that apply in each region are different, there is an IPPT issued by the Regent/Mayor, as regulated in a Regional Regulation, there is also an IPPT issued by the Head of the Land Office in the form of a Treatise on Land Technical Considerations.

As is the case in Cirebon Regency, if there is a land conversion request from agriculture to non-agriculture or by the term landing process, then if the agricultural land is in urban areas and is not a wetland (yellow line), the land conversion process can be registered immediately. The land conversion mechanism first is by obtaining a Recommendation Letter from the Bapeda Office, recommendations from the related Service with the issuance of a site plan or a drawing of a building plan signed by the Head of the Office. Next must get Recommendation from the Department of Agriculture and Food Security,

However, if the land is in the form of wetlands or is in the green lane, it must first obtain a land use permit from the Regional Development Planning Agency (BAPPEDA) of Cirebon Regency. To obtain a land use permit from BAPPEDA is not easy, because we have to bring and show administrative documents and authentic evidence of the condition of the land to be converted.

Permit is a state administrative law instrument most often used by the government in controlling the behavior of its citizens. Permits are deemed to be able to control every business and/or activity that has the potential to cause the impact of pollution and environmental damage, this is based on the essence of the permit itself which prohibits a certain person or legal entity from carrying out an activity and/or business without obtaining prior approval from the entity. or the authorized state administrative officer. ${ }^{8}$ Licensing has a vital role, because apart from being a source of $P A D$, licensing is also an instrument of legal protection for the ownership or implementation of activities. Permits are a form of approval from the authorities based on laws or government regulations, to in certain circumstances deviate from the

\footnotetext{
${ }^{8} \mathrm{NM}$ Spelt and JBJM Ten Berge, Introduction to Licensing Law, edited by Philipus M. Hadjon, Surabaya, Yuridika, 1993, p. 2
} 
provisions of the prohibition of legislation. ${ }^{9}$ Permission in a broad sense means approval from the ruler based on statutory regulations to allow certain actions or actions that are generally prohibited. ${ }^{10}$

Further in Government Regulation No. 1 of 2011 concerning the Designation and Transfer of Sustainable Food Agricultural Land Functions in article 3 explains that the purpose of controlling agricultural land conversion is to realize and ensure the availability of Sustainable Food Agricultural Land, realizing national food independence, resilience and sovereignty, increasing empowerment, income and welfare for farmers, providing business certainty for agricultural business actors, realizing ecological balance and preventing wasteful investment in agricultural infrastructure. Against land use change according to Government Regulation No. 1 of 2011 concerning the Designation and Transfer of Function of Sustainable Food Agricultural Land in article 35 has regulated limitatively that land that has been designated as Sustainable Food Agricultural Land is protected and prohibited from being converted. Transfer of land functions can be carried out by local governments in the context of land acquisition for public purposes or a disaster occurs. Meanwhile, interests Industry is not included in the public interest, which is allowed to use rice fields (productive land) for conversion. A land can be said to be sustainable food agricultural land if the land is capable of producing food that meets food needs not only in the area. Sustainable food agriculture land can supply the food needs of the surrounding area. In practice, Government Regulation No.1 of 2011 concerning the Designation and Transfer of Sustainable Food Agricultural Land Functions is often circumvented by drying up productive land so that agricultural land appears to be ordinary land in order to obtain permits for implementing land conversion.

\section{Research methods}

The approach method used in this research is a sociological juridical approach The sociological juridical approach is an approach that is carried out based on the main legal material by examining theories, concepts, legal principles and legislation related to this research.

\section{Resulut and Discussion}

\subsection{Implementation of Change of Land Function According to Government Regulation} No.1 of 2011

Pangenan District in the Regional Spatial Plan is planned and regulated by the Cirebon regency government to become a strategic area with the development of medium and large industries as stated in Article 41 paragraph (2) of the Regional Regulation of Ciebon Regency Number 7 of 2018 concerning the Cirebon Regency Spatial Plan for 2018 - 2038. All major industrial developments in the Cirebon Regency spatial plan are directed to the Pangenan Area. Strategic areas will continue to be developed to become an effective and significant producer of the economic sector for the region.

\footnotetext{
${ }^{9}$ lbid, p. 2

${ }^{10}$ Bagir Manan, In Ridwan HR, State Administrative Law, Revised Edition, Jakarta, Raja Grafindo Persada, 2010, p. 199.
} 
However, in Pangenan Subdistrict, in its existing condition, the industries that have been established have changed the use of land which was previously dry and wet rice fields.

Legislation to regulate the spatial sector needs to be made and regulated specifically. The state through its bureaucratic machinery is the focus of policy formulation and is the determining factor of a country. Futuristic policies made by the government occupy the top priority for solving community problems, especially those concerning spatial problems which have a very high level of dynamics. The regulation on the use of space and territory is based on Article 33 paragraph (3) of the 1945 Constitution which reads "Earth, Water and Natural Resources contained therein are controlled by the State and used for the greatest prosperity of the people" (Republic of Indonesia, Basic Law 1945, Chapter XIV article 33 paragraph 3). It is further regulated in various laws and regulations of the central and regional government.

Land resources in their use and utilization are included in the state property model or state property. This means that land, including the natural resources contained therein in the territory of the Republic of Indonesia, as a gift from God Almighty is the earth, water and space of the Indonesian nation and constitutes a national wealth. So it is an obligation for the Indonesian people to manage it which is aimed at realizing justice, welfare and happiness of all Indonesian people, and is obliged to preserve their lives. Article 2 of the UUPA is an embodiment of the mandate of Article 33 paragraph (3) of the 1945 Constitution that the earth, water and space, including natural resources contained therein, are controlled by the State. This has become a national political policy in the field of land, which mandates that the state controls the earth, water, and the wealth contained therein and in its use are solely aimed at creating prosperity for all Indonesian people. On the basis of the provisions of Article 2 paragraph (4) of the UUPA, the authority to control rights of the state can be delegated to the Regional Government only as necessary and does not contradict the UUPA and higher regulations. The formation of UUPA is based on Pancasila as a philosophical basis, there are articles that contain the precepts of Social Justice for All Indonesian People These precepts are spelled out in article 6, article 7, article 10 paragraph (1), article 11 paragraph (2), article 13, article 15, chapter 17, article 18, and article 53.

Based on article 2 of Act No. 26 of 2007 concerning Spatial Planning, spatial planning is carried out based on the principles of integration, harmony, harmony, balance, sustainability, utility, efficacy, openness, togetherness, partnership, protection of public interests, legal certainty, justice and accountability. However, in article 20 paragraph (3), paragraph (4), and paragraph (5) of Act No. 26 of 2007 concerning Spatial Planning regarding the period of spatial planning, it is an opening to commit violations of land conversion. This article is the basis for the formation of a review of the spatial plan 1 (one) time in 5 (five) years. Revisiting the spatial plan is an effort to see the suitability between the spatial plan and development needs that take into account the development of the strategic environment and internal dynamics, as well as the implementation of spatial use. Article 26 paragraph (4) where the regency spatial plan as referred to in paragraph (1) is reviewed 1 (one) time in 5 (five) years. In 
this regard, the implementation of spatial planning in Pangenan District is evaluated every 5 years once by following the existing conditions, this means that the condition of agricultural land can change according to community needs and regional development.

Furthermore, the mandate of Article 44 of Act No. 41 of 2009 concerning the Protection of Sustainable Agricultural Land states that land that has been designated as Sustainable Food Agricultural Land is protected and prohibited from being converted. Paragraph (2) states that for the public interest, sustainable food agricultural land may be converted. However, based on Presidential Regulation Number 65 of 2006 concerning Land Acquisition for Implementation of Development for Public Interest which is an amendment to Presidential Regulation Number 36 of 2005 , it is stated that industrial development carried out by a company is usually a Limited Liability Company in collaboration with investors not including the public interest, then Sustainable agricultural food land if it is converted to industrial purposes is not allowed.

Government in Government Regulation No. 1 of 2011 concerning the Designation and Transfer of Function of Sustainable Food Agricultural Land in article 3 aims to realize and ensure the availability of Sustainable Food Agricultural Land, control the transfer of function of Sustainable Food Agricultural Land, realize national food independence, resilience and sovereignty, increase empowerment, income and welfare for farmers, providing business certainty for agricultural business actors, realizing ecological balance and preventing wasteful investment in agricultural infrastructure. Regarding the transfer of function of Government Regulation No. 1 of 2011 concerning the Designation and Transfer of Function of Sustainable Food Agricultural Land in article 35 regulates that land that has been designated as Sustainable Food Agricultural Land is protected and prohibited from being converted.

Industry is not included in the public interest, which is allowed to use rice fields for conversion. A land can be said to be sustainable food agricultural land if the land is capable of producing food that meets food needs not only in the area. Sustainable food agriculture land can supply the food needs of the surrounding area. Cirebon Regency is one of the rice barns in West Java Province. So that in order to prevent a reduction in the amount of rice production that is not only used for Cirebon Regency, the transfer of function activities must be regulated with a policy that is more focused on protecting sustainable agricultural land so that there is legal certainty. The regional government has the right and indeed must make the District as a form of responsibility for the prosperity of its people.

Sub-districts have important and strategic roles and functions to create industrial structures with comparative and competitive advantages and increase productivity, efficiency and strengthen national economic stability. The district as one of the bases for highly competitive production and distribution activities needs to be expanded and developed to potential areas. Furthermore, the development and expansion of the District to potential regional areas will support regional economic expansion and 
decentralizationdevelopment in an effective and efficient manner efforts to strengthen the implementation of regional autonomy.

With this great opportunity, Pangenan District can contribute the largest income in Cirebon Regency. When viewed from the aspect of justice, this situation is included in utilitarian justice, namely that fair contains benefits. Fair becomes the greatest principle of happiness which becomes the goal and overrides truth and beauty. Something is the goal of a group of people who can make him happy by using his own way that is considered right. As long as happiness can be attained in this way then all rights and claims of other individuals and groups can be ignored.

In order to fulfill the aspect of justice in the conversion of agricultural land to nonagricultural functions, this situation should be in accordance with Rawls's view of the principles justice that basic freedoms must be distributed equally and must not be sacrificed for economic gain. John Rawls affirmed his view of justice that justice enforcement programs with a people's dimension must pay attention to two principles of justice, namely, first, giving equal rights and opportunities to the broadest basic freedoms as broad as the same freedom for everyone. Second, being able to rearrange the existing socio-economic disparities so that they can provide reciprocal benefits. When viewed based on the contribution of the industrial sector compared to agriculture. So the industrial sector is considered more effective in increasing economic growth in Sukoharjo Regency. An area cannot always maintain a green area because of the interests of the area. In order to fulfill aspects of justice, Economic growth in Pangenan District has been evenly distributed but not maximized. The distribution of economic results due to the existence of the District still occurs in an imbalance where not all of the surrounding communities have a positive impact on the existence of the District. As a result of changes in the use of paddy fields in Pangenan Subdistrict, Cirebon Regency, it has resulted in a decrease in paddy fields at the district and sub-district levels.

According to Rawls, justice is the principle of distributing rights and obligations, burdens and benefits/benefits that justice must maintain balance and harmony between public interests and individual interests. The provisions in article 33 paragraph 3 of the 1945 Constitution that Earth, water and natural resources contained therein must be used for the prosperity of the people, making law a tool to achieve justice according to Rawls. The use of land together with regulation and under the leadership of the state must be used as much as possible for the prosperity of the people. In the whole sense the Indonesian people are not just certain groups. So in order to achieve this goal, it is possible for citizens to control part of the land together individually to be used for the fulfillment of the personal needs of each of their families.

The implementation of the transfer of function of agricultural land to non-agriculture in Pangenan District, Cirebon Regency is oriented towards the aspect of utility justice and has not fully fulfilled the justice aspect of Rawls due to the following reasons: 
1. The function of conversion of agricultural land to industry is more concerned with economic factors.

2. Community participation in the spatial planning process is still very limited. In the planning process, the community cannot voice their opinions optimally. In the socialization of spatial use planning, the community is only given an understanding of positive impacts such as expensive land prices, areas will be developed, while the negative impact of the impact of the District on agricultural land is not disseminated.

3. Pangenan District planning policies are oriented towards achieving long-term goals that are still not on target and using short-term problem solving. Planning should have a clear management involving a third party so that its use and use are clear, equipped with a clear supervisory mechanism and development control. Planning must also pay attention to the surrounding environment where there are still many agriculture and residential areas.

4. There are no strict sanctions for violators who commit land conversion violations because the RTRW plan is dynamic so that it can be evaluated.

The conversion of agricultural land to non-agricultural land for industry requires the right solution in order to achieve justice by prioritizing common interests, namely increasing food production and increasing the economic sector from the agricultural sector and the industrial sector. Protection of farmers and their farming businesses is needed in the form of laws or government regulations so that farmers have economic incentives to work in the agricultural sector. National development policies must be aimed at the realization of a strong agricultural sector condition, which does not tend to pursue high economic growth, especially districts/cities which have regional autonomy authority. The participation of local governments and communities needs to be increased in spatial planning to utilize land according to its allotment so that social functions in achieving aspects of justice can be fulfilled. The district government with efforts to increase rice productivity that have been implemented so far so that it can be wiser so as not to lose more of the agricultural sector so that food security can be achieved and industrial needs can be fulfilled.

Overall, the legal aspects related to the conversion of agricultural land in Cirebon Regency have been sufficiently integrated to meet the criteria as a basis for consideration in granting conversion permits for industrial estate development locations to entrepreneurs. It is the government through the BPPT instrument that should be able to play a central role in managing and regulating applications for the conversion of productive agricultural land. Without the permits they issue, it is not possible for entrepreneurs to carry out housing construction or by transferring land functions. The stages of the application process for the applicant's permit to BPPT determine whether the land conversion is obeyed or violated, which in practice in the field is strongly influenced by the environmental economy politics, and others. 
The stages of the housing development permit process that the developer is intended to follow are as follows:

1. Recommendations for Transfer of Land Functions to Housing Development (Department of Agriculture, Plantation, Animal Husbandry and Forestry)

2. Location Direction Plan Fatwa (BPPT)

3. Land Technical Considerations in the Context of Issuance of Land Use Change Permits (National Land Agency)

4. Land Acquisition and Use Certificate (BPPT)

5. Feil Flood Technical Advice (Water Resources Management and Mining Service)

6. Site Plan Recommendations (Cipta Karya and Spatial Planning Office)

7. Environmental Management Efforts (UKL) and Environmental Monitoring Efforts (UPL) (Regional Environmental Agency)

8. Building Construction Permit (IMB) (BPPT)

The mechanism in internal licensing is that the flow of permits must be carried out in sequence and have been approved by the agency that handles it. Refusal to grant a license to one agency will result in the flow of subsequent licensing being unable to be fulfilled.

\subsection{Problems and Solutions in the Implementation of the Change of Function of Agricultural Land to Industrial Estates}

1. Problems in the Implementation of the Change of Function of Agricultural Land to Industrial Estates

The aspect of tenure/ownership is related to the legal relationship between humans and land, while the use/utilization aspect is related to the activity of taking benefits or added value to land resources. The provisions for the Protection of Sustainable Food Agricultural Land are intended so that certain areas of land may only be used for agricultural activities In order to implement it, it is necessary to have arrangements related to control/ownership of land so that control/ownership of land is distributed efficiently and fairly. At the same time, it is hoped that the area of land cultivated by farmers can increase adequately so as to guarantee the welfare of the farmer family and achieve adequate food production. Act No. 26 of 2007 concerning Spatial Planning (State Gazette of the Republic of Indonesia of 2007 Number 68, Supplement to the State Gazette of the Republic of Indonesia Number 4725) commands the need for protection of the area of perennial food agriculture which is regulated by law. In addition to the Law, protection of perennial land for food agriculture is related to other laws and regulations, namely Act No. 5 of 1960 concerning Basic Agrarian Principles. 41 of 2009, for the purposes of Food Independence, Security and Resilience, it is necessary to save agricultural land for food. Rescue must be done immediately because the rate of conversion of paddy fields or other food agriculture is very fast salvage of food agriculture land from existing food land or reserves that are compiled based on criteria covering land suitability, availability of infrastructure, land use, land potential and the existence of area in stretch units (Article 9). The mandate of this law needs to be followed up by identifying existing agricultural land, both irrigated and 
non-irrigated. To inhibit the rate of conversion, this law requires the establishment of Sustainable Food Agricultural Land (LP2B), Sustainable Food Agricultural Reserves (LCP2B) and Agricultural Areas. Sustainable Food (KP2B).

Efforts to protect LP2B are carried out through the establishment of an area (KP2B) which will consist of $L P 2 B$ and $L C P 2 B$ and various supporting elements. This means that apart from rice fields, various supporting elements also need to be known to determine the appropriate policies or programs. PK2B then needs to become an integral part of the Regency Spatial Plan, while LP2B and LC2B are integrated in a detailed Spatial Plan. In this law, it is also stated that agricultural food land which will be protected can become part of the area or extend outside the area. Government Regulation Number 12 of 2012 concerning Incentives to Control Sustainable Food Agricultural Land is carried out by the Government and Local Governments through the provision of Incentives.

Incentives given to farmers can be in the form of land and building tax relief, development of agricultural infrastructure, financing research and development of superior seeds and varieties, easy access to information and technology, provision of agricultural production facilities and infrastructure, guaranteed issuance of certificates of land rights on Food Agricultural Land. Sustainable through sporadic and systematic land registration, and rewards for high achieving Farmers. Farmers who receive incentives have obligations including to use the land according to its designation as Sustainable Food Agricultural Land, prevent damage to irrigation, maintain and increase soil fertility, prevent land damage, and protect the environment.

Giving incentives to farmers is an effort to improve the quality of agricultural human resources. Agricultural human resources are needed to increase the yield and quality of agricultural production. With the existence of agricultural human resources, farmers are able to innovate to create agricultural technology that is able to produce quality agricultural products in high quantities so that they can meet the need for food nationally and even internationally. Disincentive, which in this Government Regulation is called Incentive revocation, is carried out if Farmers as Incentive recipients do not carry out their obligations by not protecting their Sustainable Food Agricultural Land by violating norms, standards, procedures and criteria, and if the land has been converted.

Based on MOA No. 81 of 2012 that the release of ownership of land rights transferor performs the release of ownership of land rights to the owner of the land in accordance with the provisions of the legislation. The release of ownership of land rights is carried out through the provision of compensation to rights owners. The provision of compensation is regulated in the following manner:

a. Every owner of the converted Sustainable Food Agricultural Land must be compensated by the converting party.

b. In addition to compensation to the owner, the party converting is required to replace the value of infrastructure investment in the converted Sustainable Food Agricultural Land. 
c. Replacement of infrastructure investment value is earmarked for funding infrastructure development in replacement land locations.

d. The costs of compensation and the value of infrastructure investment and funding for the provision of replacement land come from the State Expenditure Budget, Provincial Regional Expenditure Budget and Regency/City Regional Expenditure Budget of the agency carrying out the function transfer.

The criteria for land conversion are land acquisition for public purposes which includes public roads, reservoirs, dams, irrigation, drinking water or clean water channels, drainage and sanitation, irrigation buildings, ports, airports, stations and railways, terminals, facilities public safety, nature reserves and/or power plants and networks. The description of land acquisition for public purposes is as follows: Land procurement for public roads includes the construction of state roads, provincial roads, district/city roads, and village and environmental roads as regulated in statutory regulations. Apart from the foregoing, construction of farm roads in the Allocation Area for sustainable food agriculture which functions to support increased production resulting in the conversion of land use for sustainable food agriculture does not violate applicable regulations. Land procurement for the construction of reservoirs, dams, irrigation and irrigation structures in sustainable food agriculture areas includes: construction of irrigation networks up to the tertiary level, reservoirs, lakes, trench dams, rorak, which functions to provide and conserve water in order to support sustainable land protection sustainable food agriculture.

In accordance with the definition of a state, the purpose of a state and the provisions of the existence of a state, the government's attention is of course focused on the lives of its people, which is one of the components of the establishment of the state. Idee or the noble goals of the state as stated in the Basic Law of the Constitution of the Republic of Indonesia 1945 is the welfare of the people. ${ }^{11}$ In order to fulfill its obligations in the welfare of the people in realizing land protection, independence, food security and sovereignty, the state formulates and implements policies including regulating the protection of agricultural land through the provisions of Act No. 41 of 2009 concerning the Protection of Sustainable Food Agricultural Land.

As a follow-up to Act No. 41 of 2009 concerning Protection of Sustainable Food Agricultural Land, Government Regulation Number 1 of 2011 concerning Stipulation and Transfer of Sustainable Food Agricultural Land Functions and Government Regulation Number 30 of 2012 concerning Financing of Sustainable Food Agricultural Land Protection. The provisions of Article 3 of Act No. 41 Of 4009 determine that the Protection of Sustainable Food Agricultural Land is carried out with the aim of:

a. protect the area and land for food agriculture in a sustainable manner;

b. guarantee the availability of food agriculture land in a sustainable manner;

\footnotetext{
${ }^{11}$ Abrar Saleng, Mining Law, UII Press, Yogyakarta. 2007, p. 8.
} 
c. realizing food independence, resilience and sovereignty;

d. protect the ownership of agricultural food land owned by farmers;

e. increase the prosperity and welfare of farmers and society;

f. increasing protection and empowerment of farmers;

g. increasing the provision of employment opportunities for a decent life;

h. maintaining ecological balance; and

i. realizing agricultural revitalization.

Furthermore, the provisions of Article 7 of Government Regulation Number 1 of 4012 stipulate that: "Sustainable Food Agricultural Areas are determined based on criteria, requirements and procedures for determination". The determination of agricultural areas is also related to Government Regulation Number 12 of 2012 concerning Incentives for the Protection of Sustainable Food Agricultural Land and Government Regulation Number 30 of 2012 concerning Financing of Sustainable Food Agricultural Land. Meanwhile, the provisions of Article 4 of Government Regulation Number 30 of 2012 concerning Financing of Sustainable Food Agricultural Land determine the following:

a. The Government, Provincial Governments, and Regency/City Governments allocate Financing for the Protection of Sustainable Food Agricultural Land based on their duties and authorities.

b. The allocation as referred to in paragraph (1) shall be carried out by the Minister, governors and regents/mayors in accordance with the provisions of statutory regulations.

In another part, the provisions of Act No. 26 Of 4007 concerning Spatial Planning also mandate that it is necessary to protect the area of perennial food agriculture which is closely related to the laws and regulations regarding other natural resources. Therefore, the need for the protection of sustainable food agricultural land as instructed by statutory regulations needs to be carried out by the Regional Government.

The transfer of function of agricultural land in Cirebon Regency itself has been regulated in Article 9 of the Regent RegulationCirebon Number 32 Of 4016 Concerning Transfer of Agricultural Land Functions in Cirebon Regency which explains that the conversion of agricultural land can be approved by the Regent after verification of land use change is carried out by a regional verification team formed by the Regent. In practice, entrepreneurs often make irregularities by changing the structure of productive land to become unproductive or by simply practicing drying agricultural land into non-agricultural land. In Government Regulation number 1 of 2011 concerning the stipulation of the conversion of land functions for sustainable food agriculture, article 35 paragraph (1) and paragraph (2) has been regulated in a limited 
manner that the conversion of agricultural land is only allowed for public interests and disasters,

The form of protection from the implementation of protection for sustainable agricultural land needs strictness in law enforcement. Law enforcement is the potential for efforts to uphold or function legal norms as a guide for behavior in traffic or legal relations in public and state life. In a broad sense, the law enforcement process involves all legal subjects in every legal relationship. In a narrow sense, from the point of view of the subject, law enforcement is only defined as the efforts of certain law enforcement officials to guarantee and ensure that a rule of law runs as it should. In ensuring the enforcement of the law, if necessary, the law enforcement apparatus is permitted to use force.

\section{Solution for the Change of Function of Agricultural Land into Industrial Estates}

Regarding law enforcement on the conversion of agricultural land functions, the central government and regional governments still consider that development is merely encouraging the improvement of physical infrastructure, which often sacrifices productive agricultural land. The conversion of agricultural land to residential areas, the development of public infrastructure and industrial facilities is quite alarming so that it will have an impact on the national and regional food crisis if not handled seriously. In the midst of the food self-sufficiency target, there needs to be serious steps in law enforcement and maximum protection of productive agricultural land.

The conversion of agricultural land to non-agricultural land can affect various aspects of life, including decreased food production which threatens food sovereignty, loss of farmers' livelihoods and can lead to unemployment, and loss of investment in agricultural infrastructure (irrigation) which costs very high costs. There have been many regulations that have been issued, but there is very little commitment in their implementation from the Government and the Regional Government. Act No. 1 of 2009 concerning PLP2B is complemented by local government regulations. In its implementation, these regulations have not been effective, as seen from the conversion of agricultural land functions that continue to occur and are increasingly out of control. The economic incentives contained in these government regulations are still at a normative level.

When viewed carefully, there are 3 components involved in land conversion, namely the Government, investors and the community. When viewed from the perspective of the prismatic theory put forward by Mahfud MD, the government is faced with two interests, namely group interests and individual interests. According to Mahfud MD, the character of law that will influence the legal politics of a country will be largely determined by the choice of value of interest, namely whether it is concerned with the welfare of individuals or is it concerned with the prosperity of many people. The distinction of whether or not the fulfillment of interests is based on a political 
economy perspective. Meanwhile from a social theory perspective, even from an ideological perspective. ${ }^{12}$

In the previous discussion, it has been clearly explained in Government Regulation Number 1 of 2011 concerning the Designation of a Change in the Function of Sustainable Agricultural Land that the conversion of agricultural land for industrial purposes is not justified so there is no justification if there is a deviation with any practice, especially by tricking or converting agricultural land into land of dry which is not productive. The role of law enforcement is crucial to provide a deterrent effect and deviant practices in an effort to protect agricultural land so that land conversion is not carried out.

If we look at Lawrence M. Friedman's theory, there are 3 (three) factors that greatly influence law enforcement, namely as follows: a) Legal substance or legal substance; $b$ ) Legal Structure or legal structure, including the institution; c) Legal Culture or legal culture. Friedman's theory can be used as a parameter why law enforcement in Indonesia, in terms of controlling the conversion of agricultural land functions, is not effective.

The effectiveness of the law is shown by the choice to use the law which depends on the level of compliance of the community. The law will be effective if people really act according to legal norms as they have to, that the norms are properly applied and obeyed. In Indonesia, compliance with the law depends on how much the law is valid and believed by the community as a legal force that binds their behavior. One of the things that affects law enforcement, especially the issue of land conversion is related to the legal structure or legal structure, this occurs due to the lack of coordination and consolidation between related institutions/agencies in implementing policies to control the conversion of agricultural land to non-agricultural functions. In addition, there is a lack of understanding among law enforcers related to the agrarian sector related to Article 33 paragraph 3 of the 1945 Constitution in conjunction with Article 2 of the UUPA, which emphasizes that all natural resources in Indonesia, including earth, water and space, are used for the greatest benefit of the people. Due to a lack of understanding of these rules, the government or agrarian law enforcement officers easily give permission to change the function of agricultural land on the pretext of increasing PAD and the interests of a group of people without paying attention to the interests of the small community and not caring about sustainable agricultural land. So it is not surprising that our fertile country,

\section{Closing}

\subsection{Conclusion}

1. Not all of the policy regulations regarding the conversion of agricultural land to industrial areas in Pengenan Subdistrict, Cirebon Regency, do not all balance the food sector with the industrial sector. Act No. 5 of 1960 concerning Basic Agrarian Regulations, Act No. 41 of 2009 concerning Protection of Sustainable

\footnotetext{
${ }^{12}$ Mahfud MD. Building Legal Politics to Uphold the Constitution, Jakarta, PT Raja Grapindo Persada, 2011, p. 23-24.
} 
Food Agricultural Land, and Government Regulation No. 1 of 2011 concerning the Designation and Transfer of Function of Sustainable Food Agricultural Land has been able to balance the food sector, while Act No. 26 of 2007 concerning Spatial Planning,Ciebon Regency Regulation Number 7 of 2018 concerning the Cirebon Regency Spatial Plan for 2018 - 2038 has not fully balanced the conversion of agricultural land to non-agricultural functions because there is a review every 5 (years) 1 (one) time.

2. Norms for protection of the conversion of productive land functions have been clearly defined in various laws and regulations so that implementation at the policy level should be in accordance with existing basic norms, the pull of existing interests must be placed in the corridors of the purpose of benefiting the statutory regulations on the conversion of agricultural land functions productive. Nevertheless, the conversion of productive agricultural land can still be carried out because of urgent public interest with a high priority scale after going through various stages of more in-depth studies. In this case, at several points in certain areas in Cirebon Regency, it can be seen that the consideration of the priority scale of land use change permits granted by the Cirebon Regency Licensing Service for the construction of housing areas still requires further study because in that area there are primary irrigation water channels with soil fertility quality good enough that supports food security. Consideration of the reasons for granting permits due to economic demographics solely in this case requires a more in-depth analysis because other substitution lands are still possible. Then the absence of strict sanctions for violators who commit land conversion violations is one of the main causes of agricultural land in Cirebon Regency which continues to decrease every year.

\subsection{Suggestion}

1. Determination of the amount of perennial productive agricultural land (which is maintained) is also needed to maintain the stability and sustainability of food supply by considering the population, the area of existing agricultural land, total area, population growth rate, economic growth targets, plus projected future food demand future. The flow of permits for land conversion, especially for housing development, has not been centralized or coordinated in one agency, in this case the BPPT (Integrated Licensing Service Agency) so that the entire application process seems to have not been properly monitored because there are still inconsistencies in permit approvals that can harm the licensing applicant or public interest, in addition to the unpublished detailed mapping of the entire region.

2. There is a need for strictness in the formulation of statutory norms regarding the protection of agricultural land in an effort to control the conversion of agricultural land functions, especially in the norms of sanctioning. Law enforcement against perpetrators of irresponsible conversion of agricultural land functions is an important factor to provide a deterrent effect for perpetrators of land conversion violations. 


\section{References}

Books:

[1] Abrar Saleng. (2007). Mining Law. Yogyakarta: UII Press

[2] Achmad Chulaemi. (1992). Land Procurement For Certain Purposes In Development Framework. Semarang: Magazine of Legal Issues Number $1 \mathrm{FH}$ UNDIP

[3] Adisasmita, Rahardjo. (2010). Management of Regional Income and Orchids. Yogjakarta: Graha IImu

[4] Ali Achmad Chomzah. (2005). Agrarian Law (Indonesian Land). Jakarta: Prestasi Pustaka Publisher

[5] Bagir Manan. (2010). State Administrative Law, Revised Edition. Jakarta: Raja Grafindo Persada

[6] Mahfud MD. (2011). Building Political Law, Upholding the Constitution. Jakarta: PT Raja Grapindo Persada

[7] Maria SW Sumarjo. (2008). Land in the Perspective of Economic, Social and Rights Culture. Jakarta: Kompas Gramedia

[8] Mustofa Suratman. (2013). Use of Land Rights for Industry. Jakarta: Sinar Grafika

[9] Nana Apriyana. (2011). Agricultural Land Conversion Policy in the Context of Maintaining Land Resilience, Case Study in Java Island. Jakarta: Ministry of National Development Planning/Bappenas.

[10] NM Spelt and JBJM Ten Berge. (1993). Introduction to Licensing Law. Surabaya: Yuridika

Regulations:

[1] Act No. 56 Prp of 1960 concerning the Determination of Land Areas Agriculture

[2] Law of the Republic of Indonesia Number 26 of 2007 concerning Spatial planning

[3] Act No. 41 of 2009 concerning Protection of Agricultural Land Sustainable Food

[4] Government Regulation Number 16 of 2004 concerning Land Use

[5] Government Regulation No. 1 of 2011 Concerning Assignment and Transfer of Functions Land Sustainable Food Agriculture 
[6] Joint Instruction of the Minister of Home Affairs and Regional Autonomy with the Minister Agraria dated January 5, 1961 No. Sekra 9/1/12 about Definition of Land Agriculture

[7] Regulation of the Minister of Home Affairs Number 5 of 1974 concerning Provisions Provisions Regarding the Provision and Granting of Land for Company Purposes Good In the context of investment Foreign

[8] Regulation of the State Minister for Agrarian Affairs/Head of the National Land Agency Number of 1993 concerning Procedures for Obtaining Location Permits and Rights Over the land For companies in the context of investment

[9] Decree of the State Minister for Agrarian Affairs/Head of the National Land Agency Number 21 of 1994 concerning Procedures for Acquiring Land for Internal Companies Investment Framework

[10] Regulation of the State Minister for Agrarian Affairs/Head of the National Land Agency Number 2 of 1999 concerning Location Permits

[11] Regulation of the Minister of Agrarian Affairs/Head of the National Land Agency Number 9 of 1999 concerning Procedures for Granting and Cancellation of Rights to State Land and Management Rights

[12] Regulation of the Minister of Agrarian and Spatial Planning/Head of the National Land Agency of the Republic of Indonesia Number 15 of 2018 concerning Technical Considerations of Land 